\title{
Effect of Heat Treatment on Structural and Electronic Transition of Nano-Crystalline Titanium Dioxide Film
}

\author{
Haidar Gazy Lazim AL-Sabah ${ }^{1}$, Khalid. I. Ajeel ${ }^{2}$ and Aseel Hassan ${ }^{3}$ \\ ${ }^{I}$ (Misan University, College of Basic Education, Department of Science, Iraq) \\ ${ }_{2}^{2}$ (Basrah University, College of Education for pure science, Department of Physics, Iraq) \\ ${ }^{3}$ (Sheffield Hallam University, Materials and Engineering Research Institute, Sheffield, UK)
}

\begin{abstract}
Nanocrystalline of titanium dioxide nano films were deposited by spin coating method on silicon and ITO-glass substrates at $2000 \mathrm{rpm}$, in which starting material of Titanium Isopropoxide $\left(\mathrm{C}_{12} \mathrm{H}_{28} \mathrm{O}_{4} \mathrm{Ti}\right)$.X-ray diffraction $(X R D)$ patterns confirmed thatpolycrystalline $\mathrm{TiO}_{2}$ anatase phase formation. The intensity of XRD peaks increases with the increase in heat treatment and better crystallinity takes place at higher temperature. The morphology of deposited films were characterized by atomic force microscope (AFM); with increasing heat treatment, both the particle size and surface roughness increased .The particle size value were $2.184,2.374,4.834,5.125$, and $8.336 \mathrm{~nm}$ and RMS roughness values were $0.161,0.223,0.552,0.810$ and $1.494 \mathrm{~nm}$ for films deposited at 250, 350, 450, 550 and $650{ }^{\circ} \mathrm{C}$ respectively. Optical properties measurements (Transmittance, $T$, and Absorptance, $\mathrm{A}$,) of $\left(\mathrm{TiO}_{2}\right)$ films showed high transparency. It is observed that maximum transmittance at $250^{\circ} \mathrm{C}$ for wavelength range $320-900 \mathrm{~nm}$. The optical band gap of the films has been found to be in the range 3.28-3.62 eV for the forbidden direct electronic transition and 3.45-3.75 eV for the allowed direct transition for the different heat treatment.
\end{abstract}

Keywords - Nanoanatase $\mathrm{TiO}_{2}$, Sol-Gel, XRD,AFM,Transmittance, Absorptance

\section{INTRODUCTION}

Titanium dioxide $\left(\mathrm{TiO}_{2}\right)$ has attracted considerable attention for its potential applications in optical components including solar cell, photocatalysis, chemical sensors, and optical filters[1-5]. The material can be formulated as thin films by using a variety of techniques such as pulsed laser deposition (PLD)[6-8], chemical vapour deposition $[9,10]$, and sol-gel coating $[11,12] . \mathrm{TiO}_{2}$ has three main crystal phases (antatase, rutile, and brookite ). Among these phases, anatasephase, which is a meta-stable phase, is also chemically and optically active and suitable for photocatalyst [13]. In dye-sensitized solar cells, photo-electrodes prepared using anatase phase $\mathrm{TiO}_{2}$ gives better solar cell efficiency compared to the other crystal structures. Optical properties of $\mathrm{TiO}_{2}$ include a wide band gap, high transparency in the visible spectrum and a high refractive index over a wide spectral range (from ultraviolet (UV) to the far infrared (IR)). Nanocrystalline titania $\left(\mathrm{TiO}_{2}\right.$ ) is also a promising semiconductor for applications based on its photoconductivity. The reported optical gap of $\mathrm{TiO}_{2}$ is in the range of 3-3.7 eV corresponding to the ultraviolet region of the solar spectrum [14].

In the present study, we report on the synthesis and characterization of nanocrystalline $\mathrm{TiO}_{2}$ and influences of heat treatment on structural and electronic transition of nanocrystalline titanium dioxide films prepared by sol-gel spin coating. One of the most important techniques is spectroscopic ellipsometry, which has been found favourably for non-destructive, characterization of thin solid films and bulk materials, especially semiconductors. This technique is of high sensitivity, high accuracy, of being able to easily in situ measure both optical constant and thickness simultaneously [15]. The effect of heat treatment temperatures on the particle size of the nanoanatase $\mathrm{TiO}_{2}$ film was investigated. We found that particle size could be controlled by the heat treatment temperatures in pure nanoanatase thin films.

\section{EXPERIMENTAL}

Nanocrystalline like structured $\mathrm{TiO}_{2}$ films have been prepared by sol-gel spin coating method using a standard photoresist spinner (Model 4000 Electronic Micro System). the gel was spin coated on Si and a cleaned ITO-glass substrates at $2000 \mathrm{rpm}$ for nano films of $\left(\mathrm{TiO}_{2}\right)$ prepared from Titanium Isopropoxide (TIP) of chemical construction $\left(\mathrm{C}_{12} \mathrm{H}_{28} \mathrm{O}_{4} \mathrm{Ti}\right)$ of purity $(99.99 \%)$, also from (Acetic Acid) $\left(\mathrm{CH}_{3} \mathrm{COOH}\right)$ of purity $(99.5 \%)$, and also from (Ethanol) $\left(\mathrm{C}_{2} \mathrm{H}_{5} \mathrm{OH}\right)$ with purity of $(99.7 \%)$. These materials were prepared of (Aldrich Chemicals Company). These films have been characterized by XRD, and Spectroscopic ellipsometry were investigated on $\mathrm{TiO}_{2}$ films spin coated onto silicon substrates using a Woolam M-2000V that rotated compensator spectroscopic ellipsometry in the wavelength of range from 370-1000 $\mathrm{nm}$. The fixed degree of the angle of incidence was $70^{\circ}$. The thickness of the $\mathrm{TiO}_{2}$ film was found to be approximately $70 \mathrm{~nm}$. The surface morphology was examined by atomic force microscopy (AFM-Digital Instruments Nano Scope). The optical absorptance and transmittance measurements were made on $\mathrm{TiO}_{2}$ nano films by UV-Vis spectrophotometer at a normal incident 
of light in the wavelength range of 320-900 $\mathrm{nm}$. After coating, the sol-coated glass substrate was immediately placed in a preheated oven. A furnace type, (CAUTION) was used in this work which has a temperature range of $\left(25-1000^{\circ} \mathrm{C}\right)$.

\section{RESULT AND DISCUSSION}

X-ray diffraction patterns of the $\mathrm{TiO}_{2}$ nano films have been shown in Fig. 1 to Fig. 5 for different heat treatment temperature $250,350,450,550$, and $650{ }^{\circ} \mathrm{C}$. It is obvious that the film is polycrystalline.

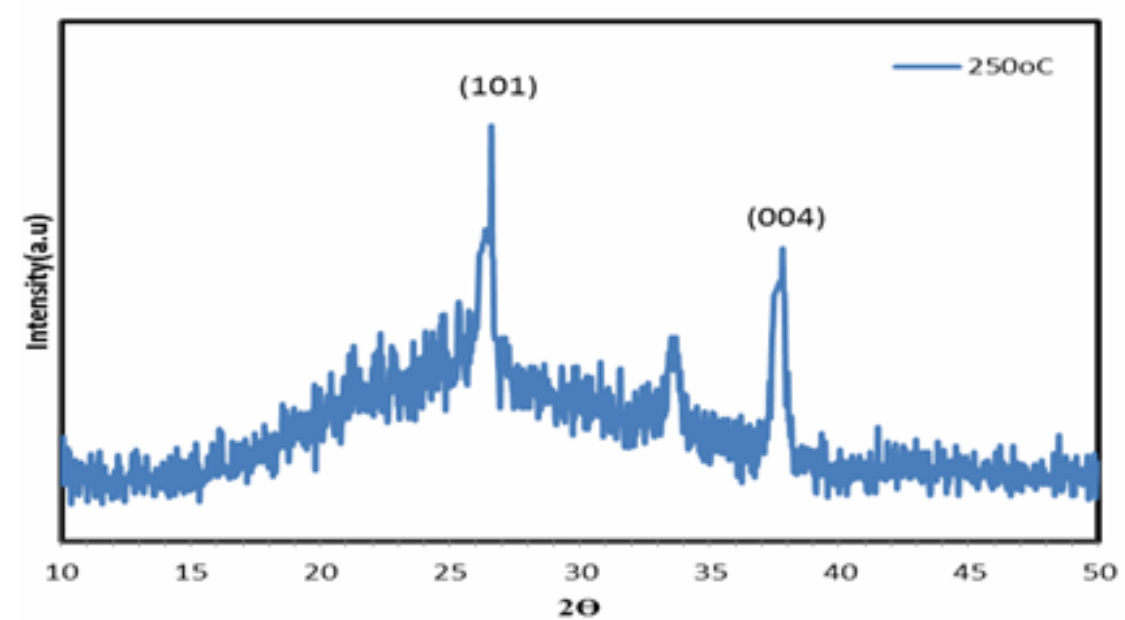

Fig.1: XRD patterns of $\mathrm{TiO}_{2}$ films grown on ITO- glass substrates at heat treatment temperature $250^{\circ} \mathrm{C}$.

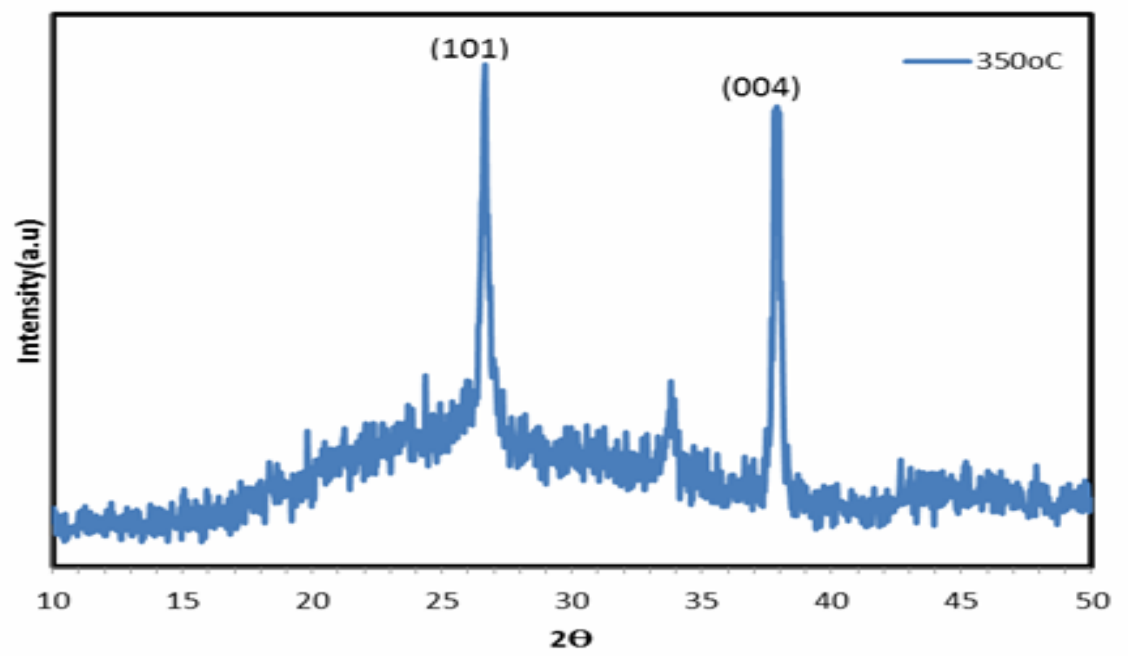

Fig. 2: XRD patterns of $\mathrm{TiO} 2$ films grown on ITO- glass substrates at heat treatment temperature $350^{\circ} \mathrm{C}$

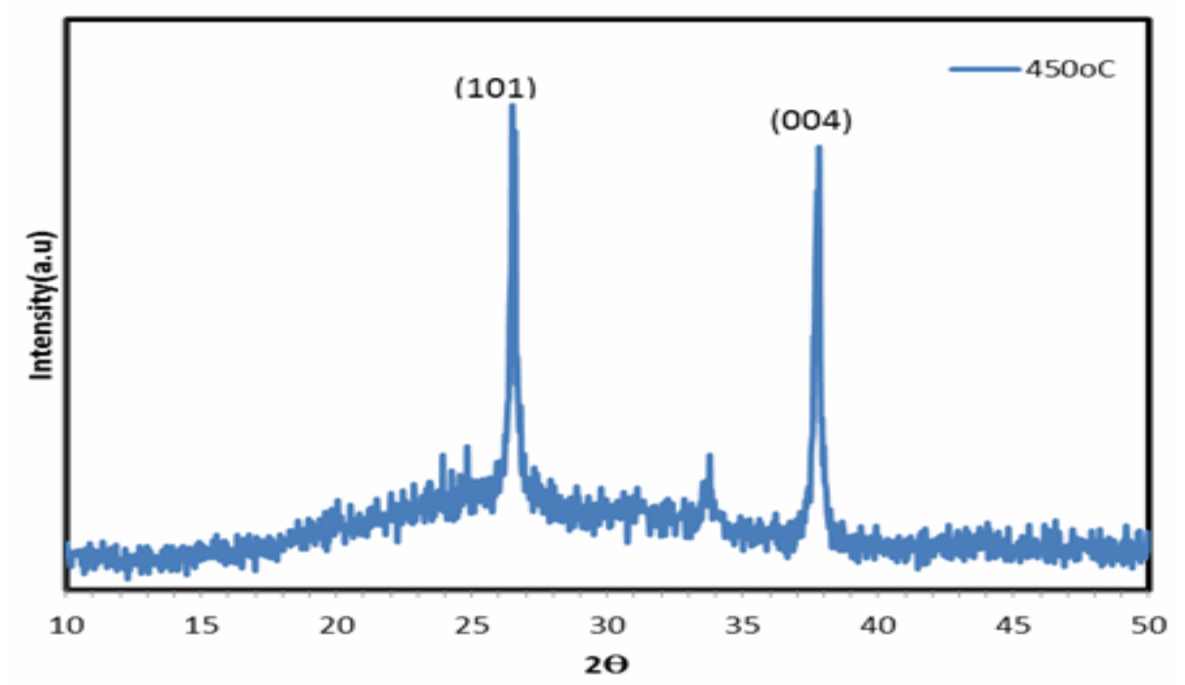

Fig. 3: XRD patterns of $\mathrm{TiO}_{2}$ films grown on ITO- glass substrates at heat treatment temperature $450^{\circ} \mathrm{C}$. 


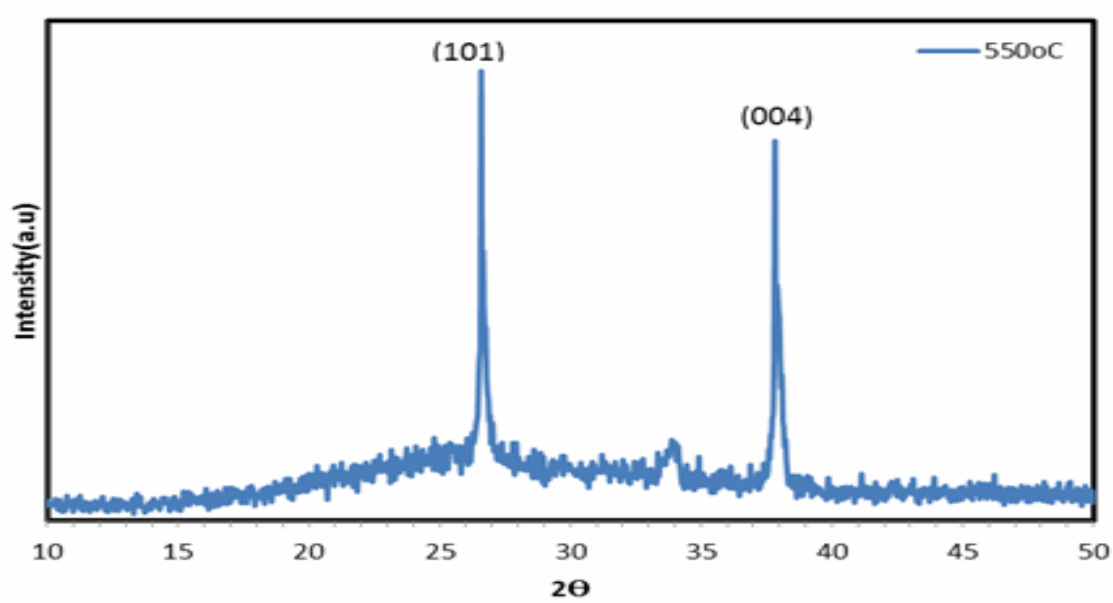

Fig. 4: XRD patterns of $\mathrm{TiO}_{2}$ films grown on ITO- glass substrates at heat treatment temperature $550^{\circ} \mathrm{C}$.

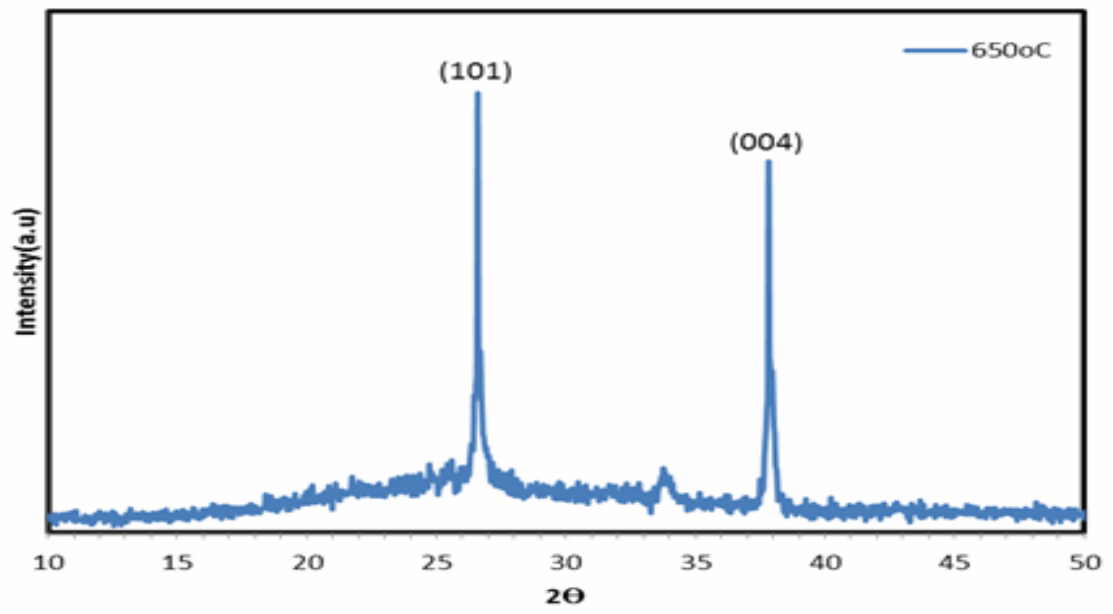

Fig. 5: XRD patterns of $\mathrm{TiO}_{2}$ films grown on ITO- glass substrates at heat treatment temperature $650^{\circ} \mathrm{C}$.

The structure of $\mathrm{TiO}_{2}$ in XRD investigation is anatase titanium dioxide, which agrees with (ASTM data 01-0711166) card. The intensity of XRD peaks increases as the heat treatment temperature increased and better crystallinity takes place at higher temperature $\left(650{ }^{\circ} \mathrm{C}\right)$. Also the rutile and brookite forms of $\mathrm{TiO}_{2}$ have not been observed during the investigation. The average crystallite size $\mathrm{D}_{101}$ of films was found to be $31.9-43.7 \mathrm{~nm}$ and the average crystallite size $\mathrm{D}_{004}$ of films was found to be $26.9-38.6 \mathrm{~nm}$ from the angular line width $\beta$ at half maximum intensity and the diffracted angle $\Theta$ employing Scherrer relation [16-17]:

$D_{h k l}=\frac{094 \lambda}{\beta \cos \theta}$

where $\lambda=0.154 \mathrm{~nm}$ is the wavelength of incident $\mathrm{x}$-ray. The observed XRD data peaks along with interplanar distance, $d$, and Miller indices $(h k l)$ are summarized in Table 1. Average values of the lattice parameters a and $\mathrm{c}$ are determined from the following relation which estimated to be 3.6 and $9.5 A^{\circ}$ respectively from substitution of interplanar distances in Table 1 into equation:

$\frac{1}{d^{2}}=\frac{h^{2}+k^{2}}{a^{2}}+\frac{\ell^{2}}{c^{2}}$

It can be seen that the values are very close to the standard values of 3.7 and $9.5 A^{\circ}$ [18].

Fig. 6 to Fig. 10 show AFM images of the pure nanoanatase $\mathrm{TiO}_{2}$ films heated at different temperatures 
Table 1: XRD data for the nanoanatase $\mathrm{TiO}_{2}$ films.

\begin{tabular}{|c|c|c|c|c|c|c|c|}
\hline \multirow[t]{2}{*}{$\begin{array}{c}\text { Temperature } \\
{ }^{\mathbf{0}} \mathbf{C}\end{array}$} & $\begin{array}{c}\text { Angle }(2 \Theta) \\
\text { degree }\end{array}$ & $\begin{array}{c}\text { Angle }(2 \theta) \\
\text { degree }\end{array}$ & $\begin{array}{c}\mathrm{d} \text { values } \\
(\AA)\end{array}$ & $\begin{array}{c}\mathrm{d} \text { values } \\
(\AA)\end{array}$ & \multirow{2}{*}{$\begin{array}{l}\text { Miller } \\
\text { indices } \\
(\mathrm{hkl})\end{array}$} & \multirow[t]{2}{*}{$\begin{array}{c}\text { FWHM } \\
\text { degree }\end{array}$} & \multirow[t]{2}{*}{$\begin{array}{c}D_{\mathrm{hk1}} \\
\mathrm{nm}\end{array}$} \\
\hline & Observed & Standard & Observed & Standard & & & \\
\hline \multirow[b]{2}{*}{250} & 26.3736 & 25.308 & 3.3794 & 3.5162 & (101) & 0.2670 & 31.9 \\
\hline & 37.5734 & 37.791 & 2.3758 & 2.3786 & (004) & 0.3247 & 26.9 \\
\hline \multirow[b]{2}{*}{350} & 26.6382 & 25.308 & 3.3464 & 3.5162 & (101) & 0.2620 & 32.5 \\
\hline & 37.9201 & 37.791 & 2.3778 & 2.3786 & (004) & 0.1948 & 45.0 \\
\hline \multirow[b]{2}{*}{450} & 26.5160 & 25.308 & 3.3616 & 3.5162 & (101) & 0.2373 & 35.9 \\
\hline & 37.7422 & 37.791 & 2.3758 & 2.3786 & (004) & 0.1948 & 45.0 \\
\hline \multirow[b]{2}{*}{550} & 26.9355 & 25.308 & 3.3101 & 3.5162 & (101) & 0.2273 & 37.5 \\
\hline & 38.1133 & 37.791 & 2.3758 & 2.3786 & (004) & 0.2598 & 33.7 \\
\hline \multirow[b]{2}{*}{650} & 26.8474 & 25.308 & 3.3208 & 3.5162 & (101) & 0.1948 & 43.7 \\
\hline & 38.0997 & 37.791 & 2.3745 & 2.3786 & (004) & 0.2273 & 38.6 \\
\hline
\end{tabular}
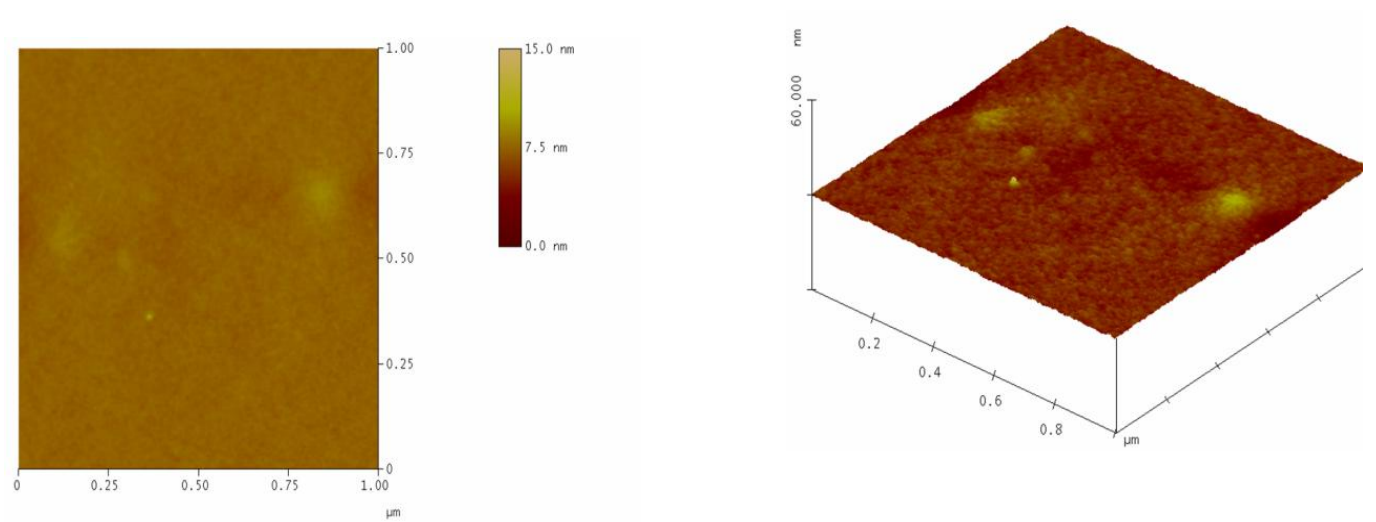

Fig. 6: Two and three-dimensional $\mathrm{AFM}$ images of $\mathrm{TiO}_{2}$ films at heat treatment temperature $250^{\circ} \mathrm{C}$.
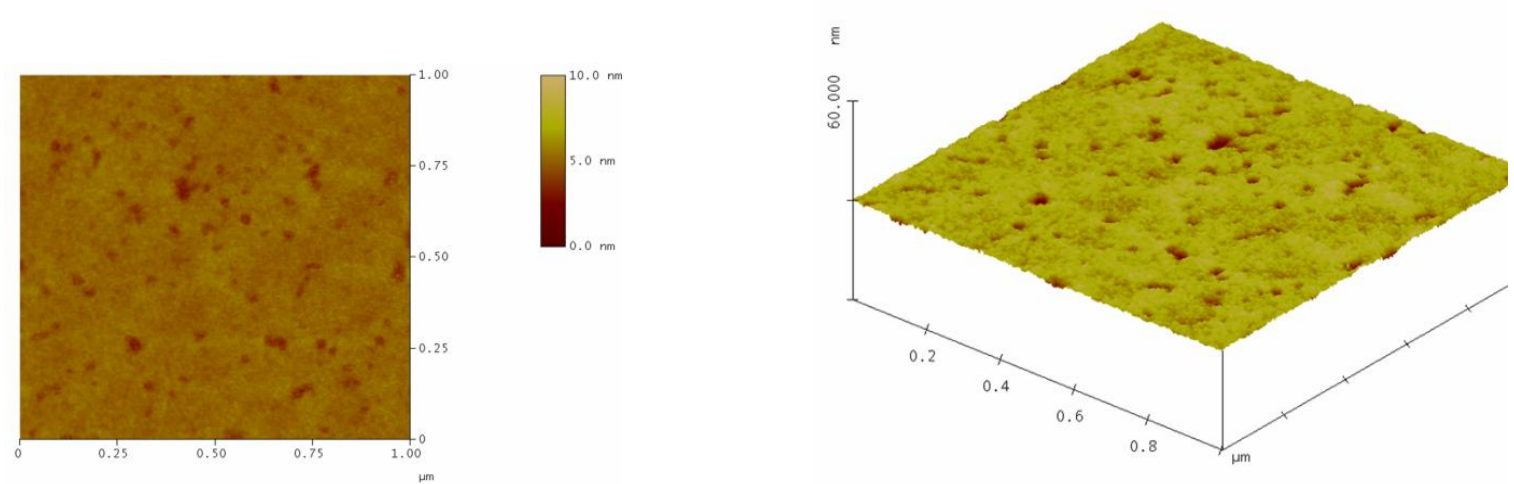

Fig. 7: Two and three-dimensional AFM images of $\mathrm{TiO}_{2}$ films at heat treatment temperature $350^{\circ} \mathrm{C}$.
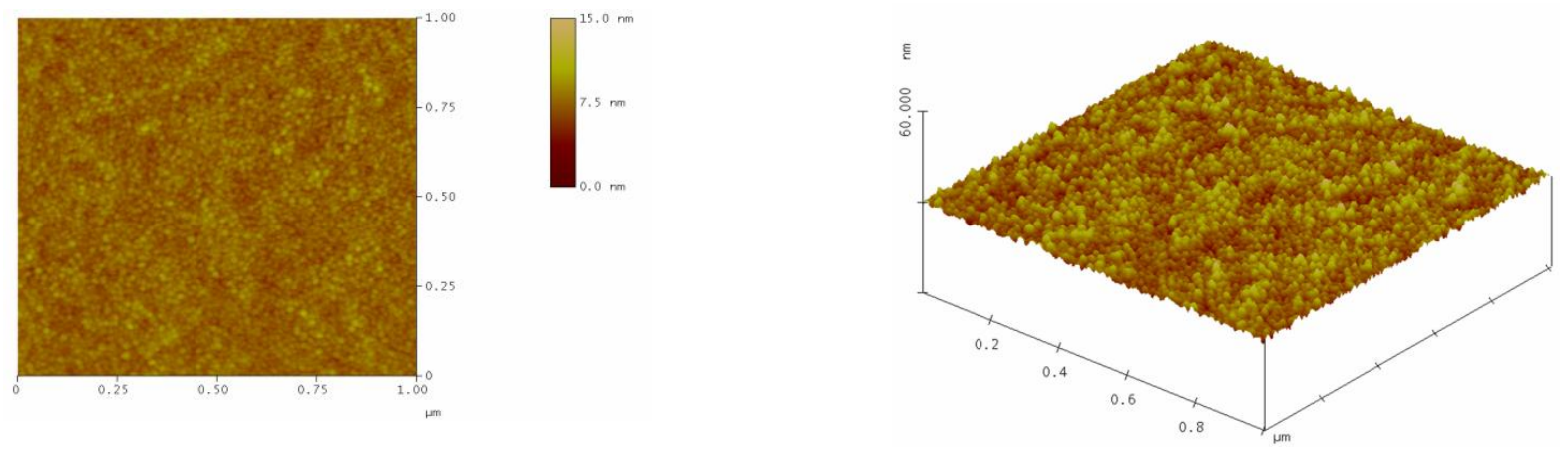

Fig. 8: Two and three-dimensional $\mathrm{AFM}$ images of $\mathrm{TiO}_{2}$ films at heat treatment temperature $450^{\circ} \mathrm{C}$. 

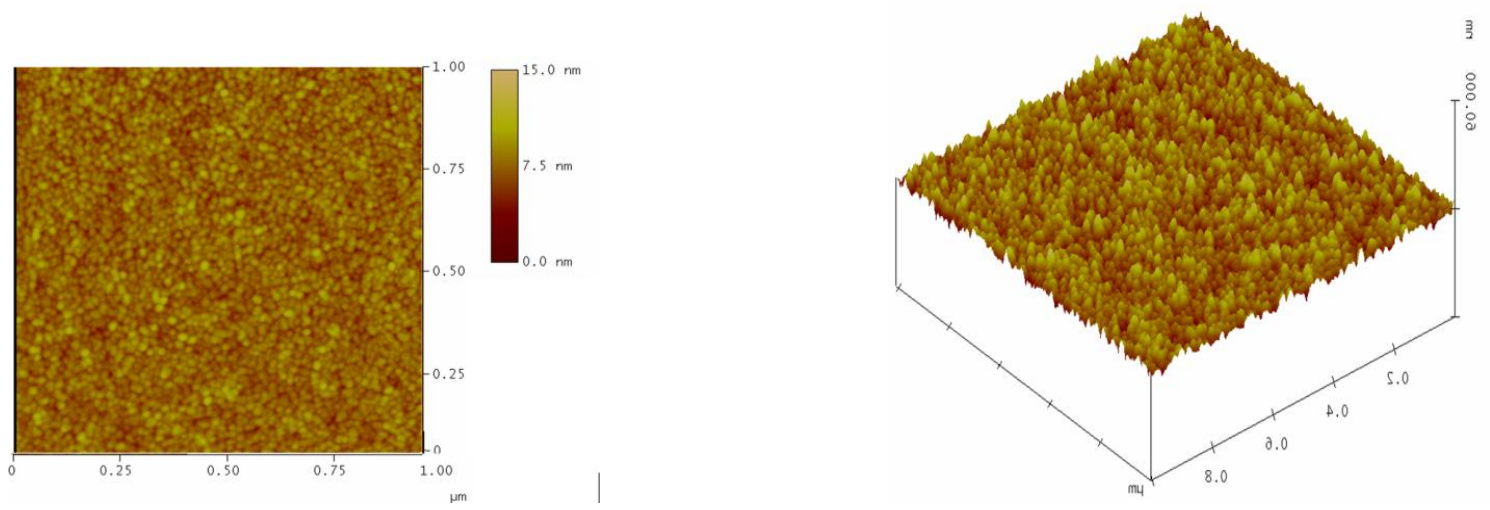

Fig. 9: Two and three-dimensional AFM images of $\mathrm{TiO}_{2}$ films at heat treatment temperature $550^{\circ} \mathrm{C}$.
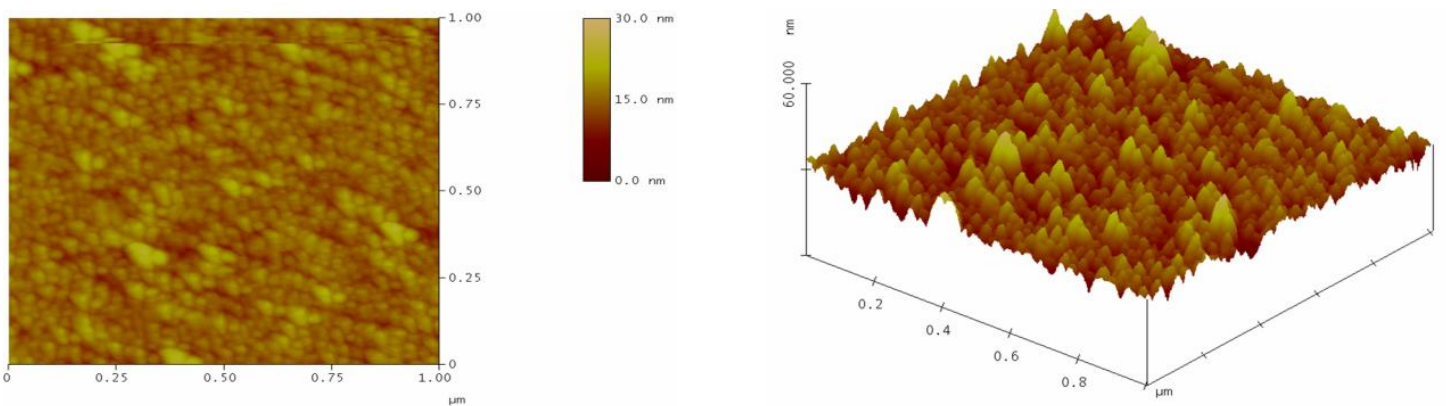

Fig. 10: Two and three-dimensional AFM images of $\mathrm{TiO}_{2}$ films at heat treatment temperature $650^{\circ} \mathrm{C}$

We observed that the particle size increased with the increasing heat treatment temperature, which was supported by the XRD results. The RMS surface roughness of the nanoanatase $\mathrm{TiO}_{2}$ films was determined to be $(0.161,0.223,0.552,0.810$ and $1.494 \mathrm{~nm})$ and the particles size are found to be $(2.184,2.378,4.534,5.125$ and $8.336 \mathrm{~nm}$ ) for the $250,350,450,550$ and $650{ }^{\circ} \mathrm{C}$ heat treatment temperature values respectively. The results were summarized at Table 2 .

Absorption spectra of pure nanoanatase $\mathrm{TiO}_{2}$ films were analysed using a UV-Vis spectrophotometer, as shown in Fig. 11.

Table 2: AFM data for the nanoanatase $\mathrm{TiO}_{2}$ films.

\begin{tabular}{|c|c|c|}
\hline Temperature $\left({ }^{\circ} \mathrm{C}\right)$ & RMS $(\mathrm{nm})$ & Particle size $(\mathrm{nm})$ \\
\hline 250 & 0.161 & 2.184 \\
& & \\
\hline 350 & 0.223 & 2.378 \\
\hline 450 & 0.552 & 4.534 \\
\hline 550 & 0.810 & 5.125 \\
\hline 650 & 1.494 & 8.336 \\
\hline
\end{tabular}

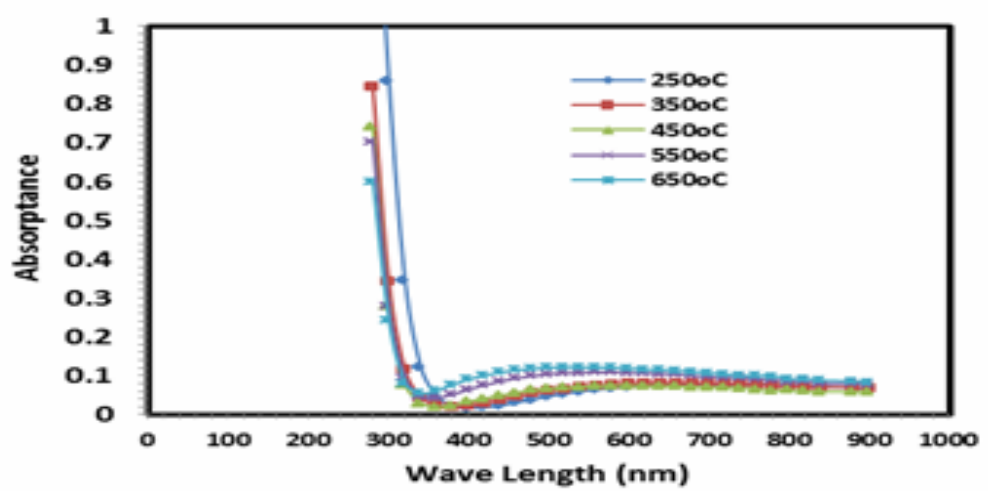

Fig. 11: Absorption spectra of $\mathrm{TiO}_{2}$ films with different heat treatment heat treatment. 
When the heat treatment temperature of the films increased, the absorption is also increased. The transmission value of the film was also investigated in the wavelength range of 320-900 nm, as shown in Fig. 12 using the $\mathrm{UV}-\mathrm{Vis}$ spectrophotometer.

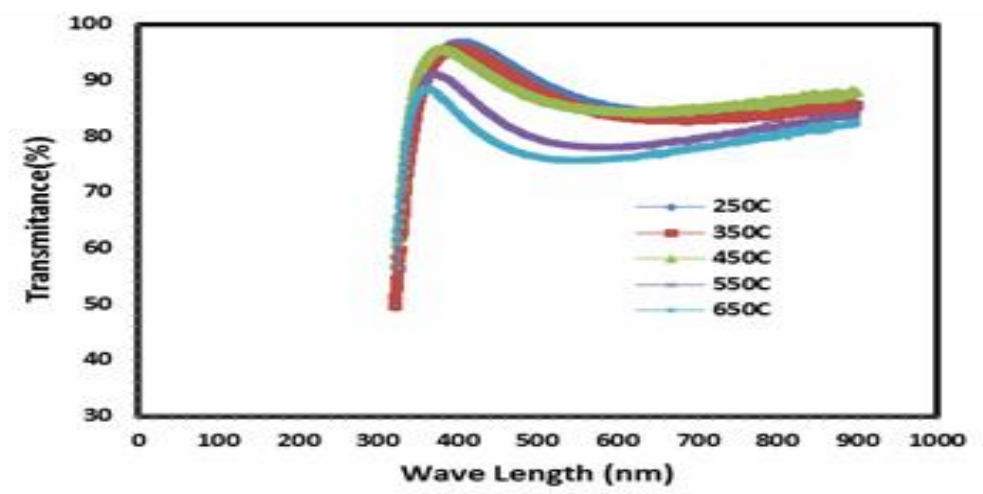

Fig. 12: Transmission spectra of $\mathrm{TiO}_{2}$ films with different heat treatment heat treatment.

It can be seen that the transmittance of the film decreased when the heat treatment temperature of the nanoanatase $\mathrm{TiO}_{2}$ film was increased.

The band gap energy calculated by Spectrophotometric data using following equation [19].

$\alpha h v=B\left(h v-E_{g}\right)^{n}$

where $\alpha$ is the absorption coefficient, $h v$ is the photon energy in $e V, E_{g}$ is the band gap energy in $e V, B$ is constant depended on type of material, $n=1 / 2$ for the allowed direct transition and $n=3 / 2$ for the forbidden direct transition.

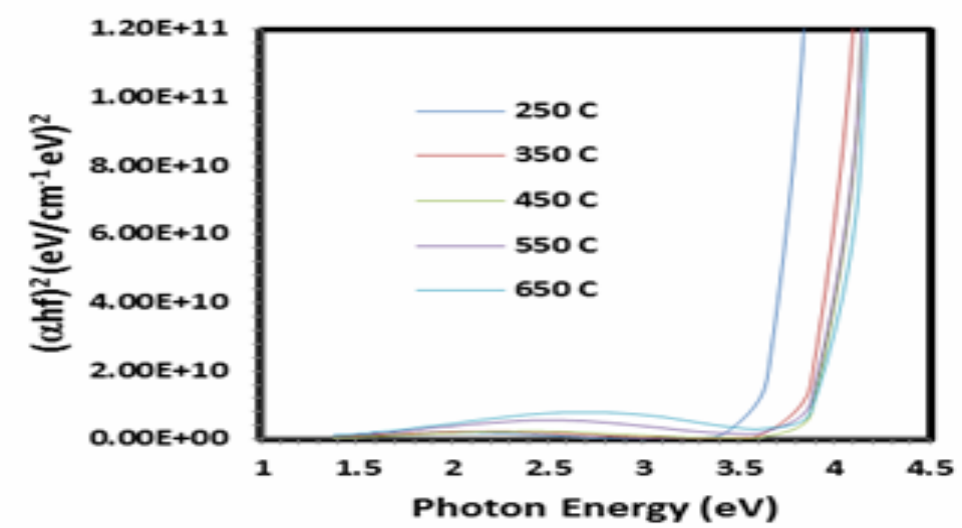

Fig. 13: $(\alpha h v)^{2}-\mathrm{h} v$ graphs of nanoanatase $\mathrm{TiO}_{2}$ films for different heat treatment temperature.

The relations are drawn between $(\alpha h v)^{2},(\alpha h v)^{2 / 3}$ and photon energy $h v$, as shown in Fig. 13 which illustrates allowed direct electronic transition and Fig. 14 illustrates the forbidden direct electronic transition.

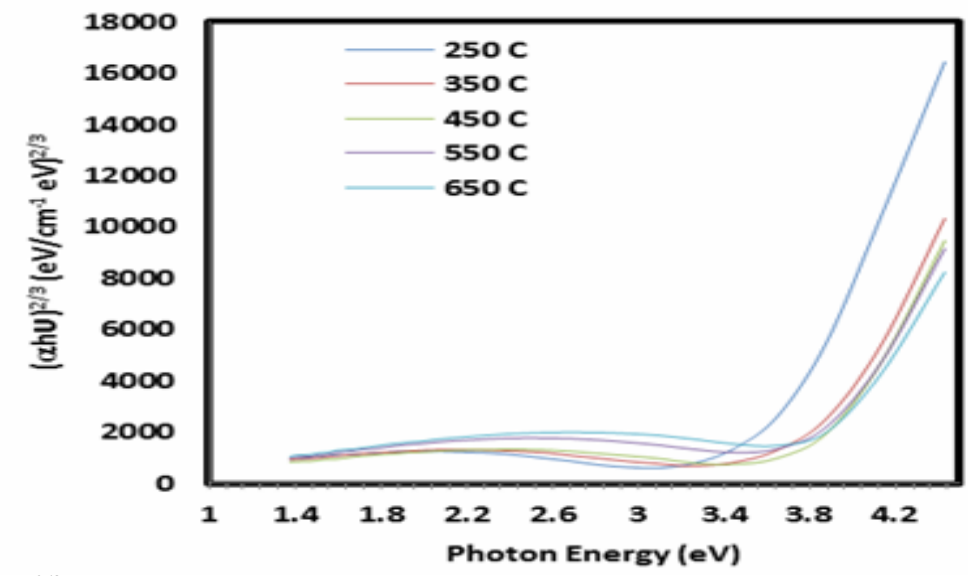

Fig. 14: $(\alpha h v)^{2 / 3}-\mathrm{h} v$ graphs of nanoanatase $\mathrm{TiO}_{2}$ films for different heat treatment temperature 
The obtained band gap values are given in Table 3. This result is in good agreement with earlier studies in which a direct optical transition was reported in the range 3.3-3.79 $\mathrm{eV}$ [20].

Table 3: direct energy gap for allowed and forbidden direct transition for nanoanatase $\mathrm{TiO}_{2}$ films.

\begin{tabular}{|c|c|c|}
\hline $\begin{array}{c}\text { Temperature } \\
\left({ }^{\circ} \mathrm{C}\right)\end{array}$ & $\begin{array}{c}\text { Allowed direct transition } \\
\mathrm{E}_{\mathrm{g}}(\mathrm{A})(\mathrm{eV})\end{array}$ & $\begin{array}{c}\text { Forbidden direct transition } \\
\mathrm{E}_{\mathrm{g}}(\mathrm{F})(\mathrm{eV})\end{array}$ \\
\hline 250 & 3.45 & 3.28 \\
\hline 350 & 3.62 & 3.39 \\
\hline 450 & 3.68 & 3.6 \\
\hline 550 & 3.69 & 3.61 \\
\hline 650 & 3.75 & 3.62 \\
\hline
\end{tabular}

The band gap energy of $\mathrm{TiO}_{2}$ films changed with different particle size, as seen in the AFM results ,Table 2, shown in Fig. 15. We observed that the particle size of pure nanoanatase $\mathrm{TiO}_{2}$ films increased with increasing band gap energy.

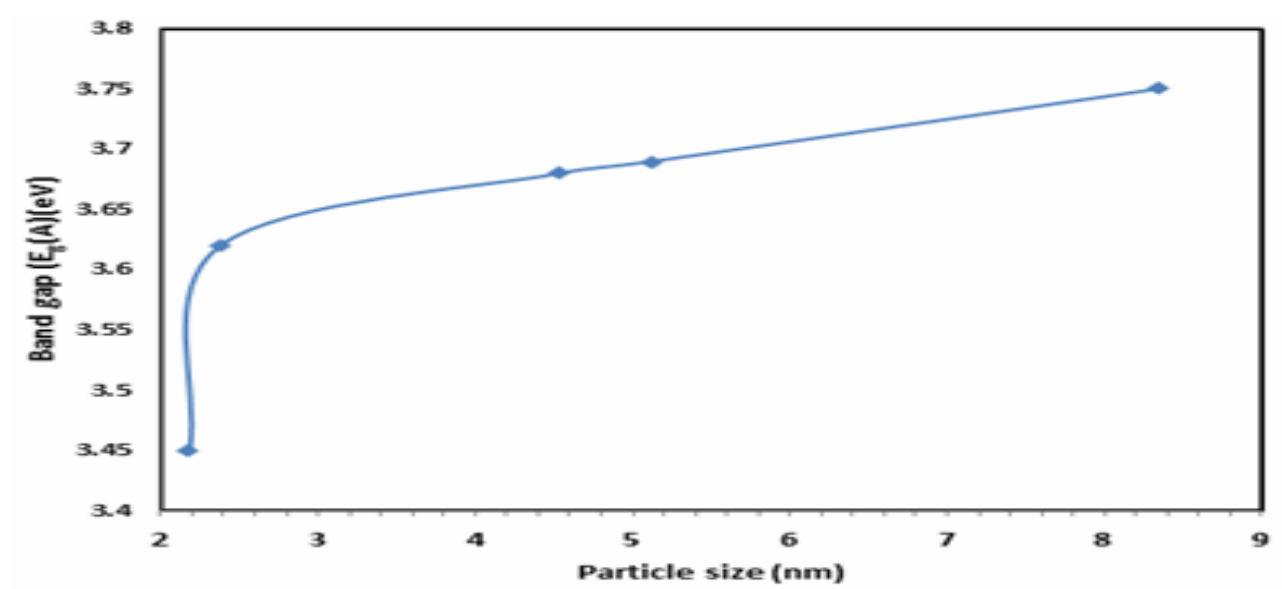

Fig. 15: Band gap energy-particle size graphs of nanoanatase $\mathrm{TiO}_{2}$ films for different heat treatment temperature.

\section{CONCLUSION}

From the present study, it can be withdrawn the following conclusions, Titanium dioxide films were prepared through a sol-gel process. The intensity of XRD peaks increases with the increase in heat treatment and better crystallinity takes place at higher temperature. The investigation of (XRD) indicates that the $\left(\mathrm{TiO}_{2}\right)$ film is polycrystalline type of (anatase).It was found that the particle size controlled by the heat treatment temperature. The results indicate that an increase in the heat treatment temperature led to the increase in the particle size of $\mathrm{TiO}_{2}$ films because of the increasing crystallization. The roughness of pure nanoanatase $\mathrm{TiO}_{2}$ films increased with increasing particle size. The optical absorptance of nanoanatase $\mathrm{TiO}_{2}$ film increased with increased heat treatment temperature, while the transmittance values of the nanoanatase $\mathrm{TiO}_{2}$ film decreased with increased heat treatment temperature. The optical band gap of the films has been found to be in the range 3.28-3.62 eV for the forbidden direct electronic transition and 3.45-3.75 eV for the allowed direct transition for the different heat treatment.

\section{REFERENCES}

[1]. S. Sharma, M. Vishwas, K. Rao and S. Mohan, Structural and optical investigations of $\mathrm{TiO}_{2}$ films deposited on transparent substrates by sol-gel technique, Journal of Alloys and Compounds, 471 , 2009, 244-247.

[2]. F. Gamez, A. Reyes, P. Hurtado, E. Guille, J. A. Anta, and B. Martiez, Nanoparticle TiO 2 Films Prepared by Pulsed Laser Deposition: Laser Desorption and Cationization of Model Adsorbents, J. Phys. Chem. C, 114, 2010, 17409-17415.

[3]. C. Ayieko1, R. Musembi1, S. Waita1, B. Aduda1 and P. Jain, Structural and Optical Characterization of Nitrogen-doped TiO 2 Thin Films Deposited by Spray Pyrolysis on Fluorine Doped Tin Oxide (FTO) Coated Glass Slides, International Journal of Energy Engineering , 2(3), 2012, 67-72.

[4]. M. Mohammadi, N. Shahtahmaseb, M. Karimipour1, and R. Sarhadd, Characterization of nanostructured Nd-doped TiO ${ }_{2}$ thin film synthesized by spray pyrolysis method: Structural, optical and magneto-optical properties, Indian Journal of Science and Technology, 5 (6) 2012, 2912-2916.

[5]. C. Ayicko, R. Musembi, S. Waita, and P. Jain, Structural and Optical Characterization of Nitrogen-doped TiO2 ThinFilms Deposited by Spray Pyrolysis on Fluorine Doped Tin Oxide (FTO) Coated Glass Slides, International Journal of Energy Engineering, 2(3),2012, 67-72.

[6]. X. Han, G. Wang, J. Jie, X. Zhu, and J. Hou, Properties of Zn1-xCoxO thin films grown on silicon substrates prepared by pulsed laser deposition, Thin Solid Films, 491, 2005, 249 - 252. 
[7]. S. Hyuck , S. Yeol, B. Jun, and I. Seongil, Pulsed laser deposition of ZnO thin films for applications of light emission," Applied Surface Science, 154, 2000, 458-461.

[8]. A. Singh, M. Kumar, R. Mehra, A. Wakahara, and A. Yoshida, Al-doped zinc oxide (ZnO:Al) thin films by pulsed laser ablation, J. Indian Inst.,81, 2001, 527-533.

[9]. R. Capan, N. Chaure, A. Hassan, Optical dispersion nanocrystalline titania thin films, Semiconductor Science and Technology, 19(7), 2004, 198-202.

[10]. D. Rathee, M. Kumar, and S. Arya, Deposition of nanocrystalline thin $\mathrm{TiO}_{2}$ films for MOS capacitors using Sol-Gel spin method with Pt and Al top electrodes, Solid State Electronics, 76, 2012, 71-76.

[11]. N. Ibrahim E. Yusrianto and Z. Ibrahim, Effect of Different $\mathrm{TiO}_{2}$ Preparation Techniques on the Performance of the Dielectric Bolometer as a Distance Sensor, Sains Malaysiana 41(8),2012, 1092-2035.

[12]. H. Shih and R. Vasant, Sol-gel $\mathrm{TiO}_{2}$ in self-organization process: growth, ripening and sintering, RSC Advances, 2(3), 2012, 22942301.

[13]. M. Landmann, E. Rauls and W. Schmidt, The electronic structure and opticalresponse of rutile, anatase and brookite TiO ${ }_{2}$, J. Phys. 24(5), 2012, 1-6.

[14]. D. ThiThanh Lea, D.Vuongb, and N. Van Duya, Preparation and characterization of solid n-TiO2/p-NiO hetrojunction electrodes for all-solid-state dye-sensitized solar cells, Solid State Electronics 53, 2009, 1116-1125.

[15]. H. Jiang, Q. Wei, Q. Xiyao, Spectroscopicellipsometry characterization of $\mathrm{TiO}_{2}$ thin films prepared by the sol-gel method, Ceramics International, 34, 2008, 1039-1042.

[16]. E. Lee, J. Hong, H. Kang and J. Jang, Synthesis of $\mathrm{TiO}_{2}$ nanorod-decorated graphene sheets and their highly efficient photocatalytic activities under visible-light irradiation, Jornal of Hazardous Materials 219( 220), 2012, 13- 18

[17]. I. Ganesh, A. Gupta, P. Kumar, P. Chandra, K. Radha, G. Padmanabham, and G. Sundararajan, Preparation and characterization of Co-doped $\mathrm{TiO}_{2}$ materials for solar lightinduced current and photocatalytic applications, Materials Chemistry and Physics 135(4), 2012, 220-234.

[18]. ASTM data (01-071-1166) card.

[19]. A. P. Singh, S. Kumari, and R. Shrivastav, Iron doped nanostructured $\mathrm{TiO}_{2}$ for photoelectrochemical generation of hydrogen, International Journal of Hydrogen Energy 33(2), 2008, 5363-5368.

[20]. Z. Wang, U. Helmersson, and P. Kall, Optical properties of $\mathrm{TiO}_{2}$ thin film prepared by aqueous sol-gel at low temperature, Thin Solid Film, 405(9), 2002, 50-54. 